\begin{tabular}{ccc} 
Tersedia online di: http://ejournal-balitbang.kkp.go.id/index.php/jppi & JURNAL \\
e-mail:jppi.puslitbangkan@gmail.com & PENELITIAN \\
PERIKANAN & INDONESIA \\
JURNAL PENELITIANPERIKANANINDONESIA & Volume 23 Nomor 1 Maret 2017 \\
p-ISSN: 0853-5884 & e-ISSN: 2502-6542 \\
Nomor Akreditasi: 653/AU3/P2MI-LIPI/07/2015 & \\
\hline
\end{tabular}

\title{
DISTRIBUSI DAN POTENSI SUMBER DAYA IKAN PELAGIS DI WILAYAH PENGELOLAAN PERIKANAN NEGARA REPUBLIK INDONESIA 573 (WPP NRI 573) SAMUDERA HINDIA
}

\section{DISTRIBUTION AND POTENTIAL RESOURCES OF PELAGIC FISH IN FISHERIES MANAGEMENT AREA OF THE REPUBLIC INDONESIA 573 (FMA 573) INDIAN OCEAN}

\author{
Asep Ma'mun*1, Asep Priatna', Thomas Hidayat' dan Nurulludin' \\ ${ }^{1}$ Balai Penelitian Perikanan Laut, Komplek Pelabuhan Perikanan Samudera, Komp. Pelabuhan Nizam Zachman, \\ JI. Muara Baru Ujung, Jakarta Utara-14430, Indonesia \\ Teregistrasi I tanggal: 30 Maret 2017; Diterima setelah perbaikan tanggal: 10 April 2017; \\ Disetujui terbit tanggal: 21 April 2017
}

\begin{abstract}
ABSTRAK
Pengelolaan perikanan tangkap yang lestari membutuhkan informasi potensi dan pola penyebaran sumber daya ikan yang dimanfaatkan. Penelitian ini bertujuan untuk mengetahui distribusi dan potensi sumber daya ikan pelagis di WPP NRI 573 (perairan Samudera Hindia) dengan metode akustik. Hasil penelitian menunjukan, penyebaran densitas cukup tinggi untuk ikan pelagis ditemukan di perairan selatan Pangandaran hingga wilayah Jogjakarta. Sumber daya ikan pelagis kecil yang terdeteksi didominasi oleh ukuran ikan dengan kisaran panjang antara $25-28 \mathrm{~cm}$ dan ikan pelagis besar di dominasi oleh ukuran ikan $28-31 \mathrm{~cm}$. Nilai rata-rata kepadatan stok untuk ikan pelagis kecil $0,041 \mathrm{ton} / \mathrm{km}^{2}$ dan ikan pelagis besar sebesar $0,14 \mathrm{ton} /$ $\mathrm{km}^{2}$. Potensi lestari ikan pelagis kecil sebesar 292.092 ton/tahun dan ikan pelagis besar sebesar 505.941 ton/tahun. Nilai tersebut dapat dijadikan dasar dalam upaya pengelolaan dan pemanfaatan perikanan pelagis.
\end{abstract}

Kata Kunci: potensi; sebaran; ikan pelagis; hidroakustik; WPP NRI 573

\begin{abstract}
The sustainable management is needed information on the stock and distribution pattern of fish. This study aims to determine distribution and potential of fish resources especially for pelagic species in FMA 573 (Indian Ocean) by using acoustic method. Result of research indicated that, high density for pelagic fish found in south Pangandaran to Jogjakarta. The results obtained also that, the detected small pelagic fish were dominated by the fish size ranged between $25-28 \mathrm{~cm}$ and large pelagic fish was dominated by fish size of $28-31 \mathrm{~cm}$. The average of the stock density for small pelagic fish was $0,041 \mathrm{ton} / \mathrm{km}^{2}$ and large pelagic fish of $0.14 \mathrm{ton} / \mathrm{km}^{2}$. The sustainable potential of the small pelagic fish amounted to 292.092 ton/year and the large pelagic fish amounted to 505.941 ton/year. These values can be used as the basic management and utilization of pelagic fisheries in the waters region.
\end{abstract}

Keywords: potential; distribution; pelagic fish; hidroacoustics; FMA 573

\section{PENDAHULUAN}

Pemanfaatan sumberdaya ikan yang berkesinambungan merupakan hal yang penting dilakukan agar kelestarian sumber daya ikan dapat terjaga. Berdasarkan Permen KP No.01 thn 2009 tentang Wilayah Pengelolaan Perikanan, WPP-NRI
573 meliputi perairan Samudera Hindia sebelah selatan Jawa hingga sebelah Selatan Nusa Tenggara, Laut Sawu, dan Laut Timor bagian Barat (Anonimus, 2009). Masyarakat yang bermukim sepanjang garis pantai WPP NRI 573, sebagian besar memiliki mata pencaharian utama sebagai nelayan, khususnya nelayan perikanan tangkap. Jenis hasil tangkapan 
yang didaratkan oleh nelayan yang berasal dari perairan WPP NRI 573 umumnya didominasi oleh ikan pelagis. Ikan pelagis kecil yang tertangkap meliputi ikan kembung (Rastelliger spp), ikan layang (Decapterus spp) dan ikan selar (Selaroides sp). Menurut Peraturan Menteri KP No.47 Tahun 2016 estimasi total potensi 294.092 ton/tahun. Sedang untuk ikan pelagis besar tercatat 505.941 ton/tahun (Anonimus, 2016). Jenis ikan ikan pelagis besar tidak termasuk jenis ikan tuna: (madidihang, mata besar, albakor, tuna sirip biru dan cakalang) karena estimasi potensinya didasarkan hasil kajian Indian Ocean Tuna Commission (IOTC). Hasil tangkapan perikanan pelagis di wilayah WPP NRI 573 pada periode 2001-2011 mengalami penurunan, dan hal ini mengindikasikan terjadinya penurunan stok (Suman et al, 2014).

Pengelolaan perikanan tangkap yang lestari sangat tergantung pada hasil penelitian sumberdaya yang terkini. Penelitian ini dilakukan untuk memberikan gambaran tentang distribusi dan potensi sumber daya ikan pelagis kecil besar dan sebaran sumber daya ikan di WPP NRI 573 (perairan Samudera Hindia) dan diharapkan dapat digunakan sebagai dasar pemanfaatan sumberdaya ikan pelagis dan pengelolaanya secara berkelanjutan.

\section{BAHAN DAN METODE Pengumpulan Data}

Penelitian dilaksanakan pada tanggal 22 September sampai dengan 15 Oktober 2015 dengan menggunakan KR. Baruna Jaya IV yang dilengkapi dengan peralatan hidroakustik untuk keperluan estimasi stok sumberdaya ikan secara langsung. Lintasan kapal untuk pengumpulan data hidroakustik menggunakan transek zigzag dibagi menjadi dua lintasan, dengan panjang lintasan total mencapai 3.078 $\mathrm{nm}$ atau $5.700 \mathrm{~km}$ (Gambar 1).

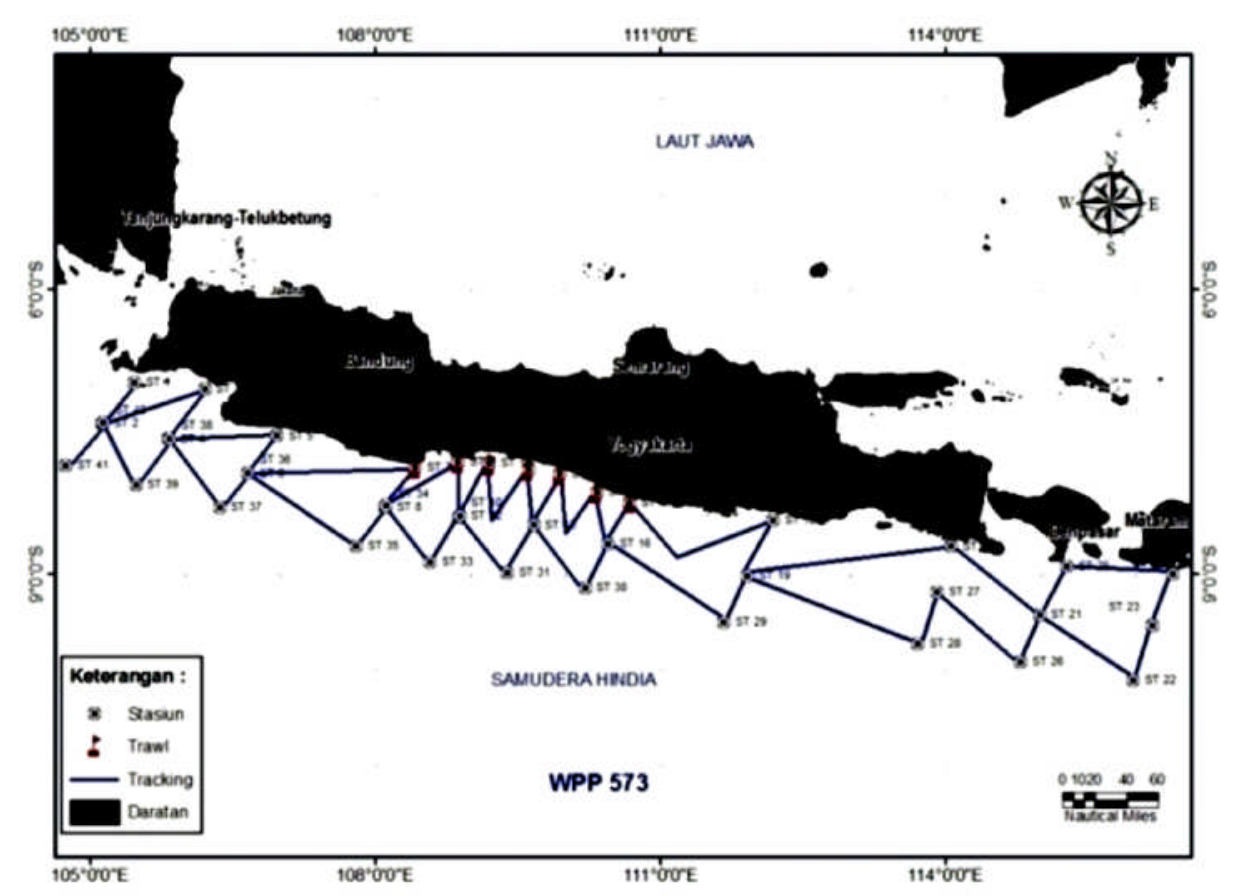

Gambar 1. Jalur transek hidroakustik untuk estimasi sumberaya ikan.

Figure 1. Tracking hydroacoustic for estimation of fish stock.

Akuisisi data hidroakustik menggunakan portable scientific echosounder SIMRAD EY60.Transducer ditempatkan pada badan kapal di lambung kanan dengan akuisisi data dijalur pemeruman dari kedalaman $5 \mathrm{~m}$ sampai kedalaman $2000 \mathrm{~m}$. Penggunaan frekuensi rendah sesuai untuk perairan yang lebih dalam dan ini sesuai dengan topografi perairan di WPP NRI 573, sehingga hasil kajian stok ikan diharapkan akan lebih baik (Lee, 2012). Analisa data estimasi stok sumberdaya ikan pelagis dilakukan hingga kedalaman 500 m dengan analisa per-strata sedalam $25 \mathrm{~m}$ dengan kecepatan kapal pemeruman 7-8 knots. Data yang dikumpulkan adalah nilai dari target strength (TS), area back-scattering coeficient $\left(\mathrm{s}_{\mathrm{A}}\right)$ yang berfungsi sebagai dasar untuk proses kuantifikasi dengan echointegrator (Lee et al., 1995). Pengaturan parameter pada sistem echosounder disajikan pada Tabel 1. 
Tabel 1. Setting parameter untuk echosounder tipe EY60

Table 1. Setting of parameter for echosounder EY60

\begin{tabular}{|c|c|}
\hline Parameter & Value \\
\hline Frequency & $38 \mathrm{KHz}$ \\
\hline Pulse Duration & $0,512-1,024 \mathrm{~ms}$ \\
\hline Power transmit & $600-1500$ watt \\
\hline Sound speed & $1540-1548 \mathrm{~m} / \mathrm{s}$ \\
\hline Absorption Coefficient & $6-7,2 \mathrm{~dB} / \mathrm{Km}$ \\
\hline SV threshold & $-70 \mathrm{~dB}$ \\
\hline TS threshold & $-60 \mathrm{~dB}$ \\
\hline
\end{tabular}

Pada echosounder tipe EY60, hasil pengamatan hidroakustik (echogram) dicatat dalam bentuk file-file digital (raw, .bot, .idx). Keluaran data akustik yaitu berupa distribusi data target strength (TS) dalam satuan desibel sebagai indeks ukuran ikan, serta data volume backscattering strength (SV) sebagai indeks kepadatan dari suatu kumpulan target ikan yang terdeteksi.

Validasi bobot dan ukuran panjang ikan menggunakan data hasil tangkapan sampingan trawl dan dikombinasikan dari hasil tangkapan nelayan pukat cincin (purse seine), serta nelayan pancing tonda disekitar di wilayah survei. Jumlah ikan layang (Decapterus macarellus) yang dianggap mewakili jenis ikan pelagis kecil yang digunakan untuk sampel, untuk perhitungan hubungan panjang berat sebanyak 258 ekor, sedangkan untuk jenis ikan pelagis besar diwakili oleh ikan tongkol komo (Euthynnus affinis) dengan jumlah sampel sebanyak 155 ekor.

\section{Pengolahan dan Analisis Data}

Untuk mengetahui komposisi ukuran ikan yang terdeteksi oleh echosounderberdasarkan kedalaman, dilakukan pembagian strata kedalaman dengan selang 25 meter, namun untuk lapisan kedalaman teratas dimulai dari kedalaman $5 \mathrm{~m}$ untuk mengurangi terjadinya noise dari mesin kapal. Data akustik diolah dengan menggunakan software SONAR ver.5 dengan Elementary Distance Sampling Unit (EDSU) sekitar $1 \mathrm{~nm}$. Hasil ekstraksi berupa nilai area back-scattering coeficient $\left(\mathrm{s}_{\mathrm{A}}, \mathrm{m}^{2} / \mathrm{nmi}^{2}\right)$ dan distribusi nilai target strength (TS) ikan tunggal dalam satuan decibel (dB) yang merupakan indeks refleksi ukuran ikan tunggal.

Sebaran komposisi berdasarkan ukuran ikan dinyatakan dalam target strength (TS) dengan satuan $\mathrm{dB}$ yang dapat dikonversikan sebagai ukuran panjang ikan. Hubungan TS dan óbs (backscattering crosssection, $\mathrm{m}^{2}$ ) dihitung berdasarkan rumus dari MacLennan \& Simmonds (2005) yaitu:

TS $=10$ log óbs.
Persamaan untuk densitas ikan $(\rho A$, individu/nmi²) adalah:

$\rho A \quad=$ sA/óbs.

Panjang ikan(L) berhubungan dengan óbs yaitu:

óbs $=a L^{b}$

Konversi nilai TS menjadi ukuran panjang (L) diperoleh dari

$\mathrm{TS}=20 \log \mathrm{L}+\mathrm{A}$.

Dimana $A$ adalah nilai TS untuk $1 \mathrm{~cm}$ panjang ikan (normalized TS). Untuk ikan pelagis kecil digunakan persamaanTS $=20 \log L-73,97$ (Hannachi et al., 2004) berupa formulasi dari ikan sarden (Sardina pilchardus), sedangkan untuk ikan pelagis besar digunakan persamaan $\mathrm{TS}=25,26 \log \mathrm{FL}-80,62$ (yang merupakan formulasi ikan tuna sirip kuning (Thunnus albacares)(Bertrand \& Josse, 2000). Dalam estimasi kelimpahan ikan, ukuran ikan pelagis yang dihitung didasarkan pada komposisi panjang hasil tangkapan nelayan yaitu ikan layang (Decapterus macarellus) dan ikan tongkol komo (Euthynnus affinis). Ikan layang dan ikan tongkol komo merupakan ikan pelagis yang dominan di WPP NRI 573. Ikan pelagis besar yang dianalisis pada tulisan ini tidak termasuk ikan cakalang dan tuna. Komposisi hasil tangkapan yang diperoleh, digunakan sebagai dasar untuk memisahkan cakalang dan juvenile tuna dari angka stok ikan pelagis besar berdasarkan hidroakustik.

Menurut Hile (1936) dalam Effendi (2002), hubungan panjang $(\mathrm{L})$ dan bobot $(\mathrm{W})$ dari suatu spesies ikan yaitu:

$\mathrm{W}=\mathrm{a} \mathrm{L}^{\mathrm{b}}$

Menurut Simmonds \& MacLennan (2005) persamaan panjang dan bobot untuk mengkonversi panjang dugaan menjadi bobot dugaan adalah: 
$W t=a\left\{\sum_{1}^{i}\left\{n i(L i+N / 2)^{b+1}-(L i-N / 2)^{b+1}\right\} /\{(b+1 N)\}\right.$

dimana:

$\mathrm{Wt}=$ bobot total (gram)

$\Delta L \quad=$ selang kelas panjang $(\mathrm{cm})$

$\mathrm{Li} \quad=$ nilai tengah dari kelas panjang $\mathrm{ke}-\mathrm{i}(\mathrm{cm})$

$\mathrm{ni} \quad=$ jumlah individu pada kelas ke-i

$\mathrm{a}, \mathrm{b}=$ konstanta untuk spesies tertentu

Untuk analisis sebaran spasial sumberdaya ikan, kepadatan ikan yang terdeteksi selama akuisisi data akustik dinyatakan dalam nilai densitas relatif (jumlah individu per luasan area, dengan satuan $\mathrm{ikan} / \mathrm{m}^{3}$ ). Sebaran komposisi berdasarkan ukuran ikan dinyatakan sebagai estimasi ukuran rata-rata didasarkan pada nilai TS yang dinyatakan dalam satuan cm (Mun et al., 2006; Lee \& Shin, 2005; Yoon \& Ha, 1998). Nilai TS tersebut kemudian akan digunakan sebagai dasar pembagian kelompok sumber daya, mengingat nilai TS pada setiap individu memiliki nilai yang berbeda-beda (Korneliussen et al., 2009; Kim et al., 1998). Adapun asumsi yang digunakan untuk struktur ukuran ikan adalah, perbedaan species ikan dianggap tidak memberikan pengaruh nyata dan pengelompokan ikan didasarkan pada selang kelas ukuran ikan yang telah ditentukan. Ikan pelagis kecil memiliki ukuran 5-28 cm (TS - $60 \mathrm{~s} /$ $\mathrm{d}-45 \mathrm{~dB}$ ) dan ikan pelagis besar memiliki ukuran 28$58 \mathrm{~cm}$ (TS - $44 \mathrm{~s} / \mathrm{d}-37 \mathrm{~dB}$ ). Hasil analisis ditampilkan dalam bentuk grafik dan sebaran spasial berdasarkan posisi geografis.

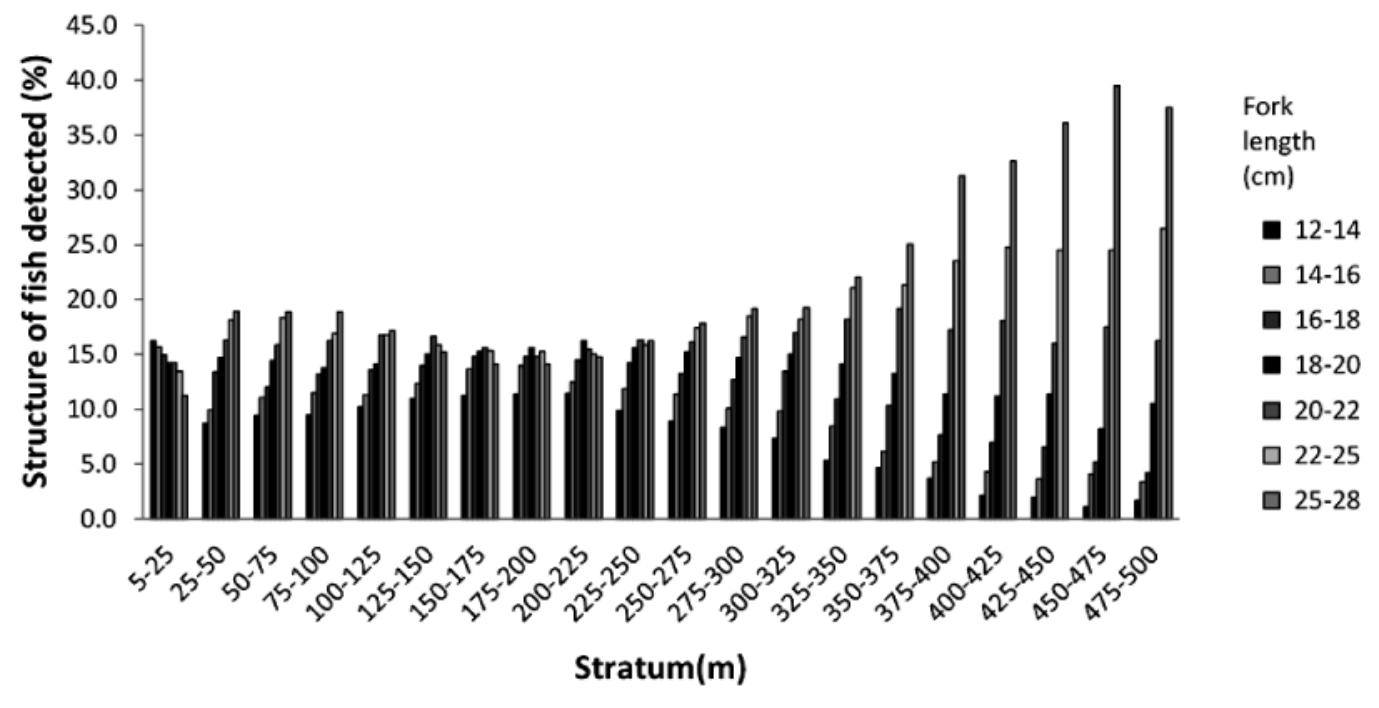

Gambar 2. Struktur ukuran ikan pelagis kecil berdasarkan kedalaman berdasarkan suvei akustik.

Figure 2. Length structure of small pelagic fish based on layer depth by acoustic survey. 


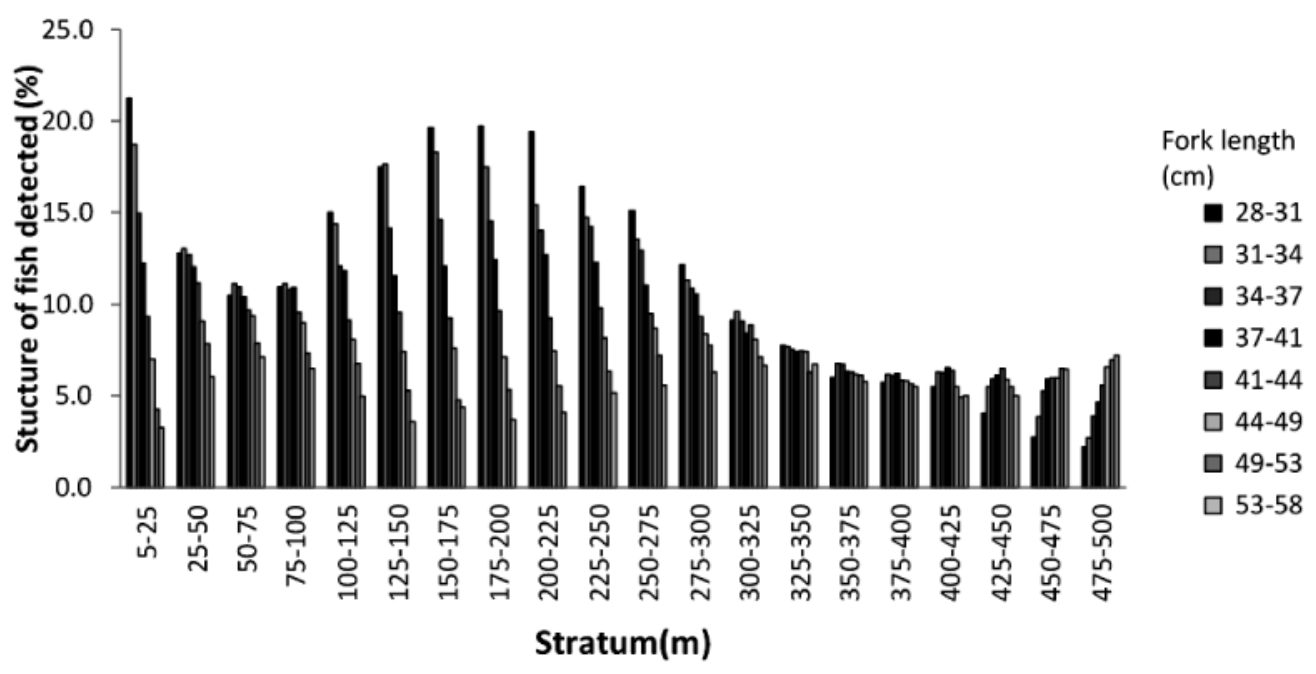

Gambar 3. Struktur ukuran ikan pelagis besar berdasarkan kedalaman berdasarkan suvei akustik.

Figure 3. Length structure of large pelagic fish based on layer depth by acoustic survey.

Distribusi ukuran panjang ikan dari hasil komposisiukuran ikan pelagis kecil didominasi oleh ikan hidroakustik dan hasil tangkapan, menunjukkan bahwa dengan ukuran kelas modus panjang $25-28 \mathrm{~cm}$.
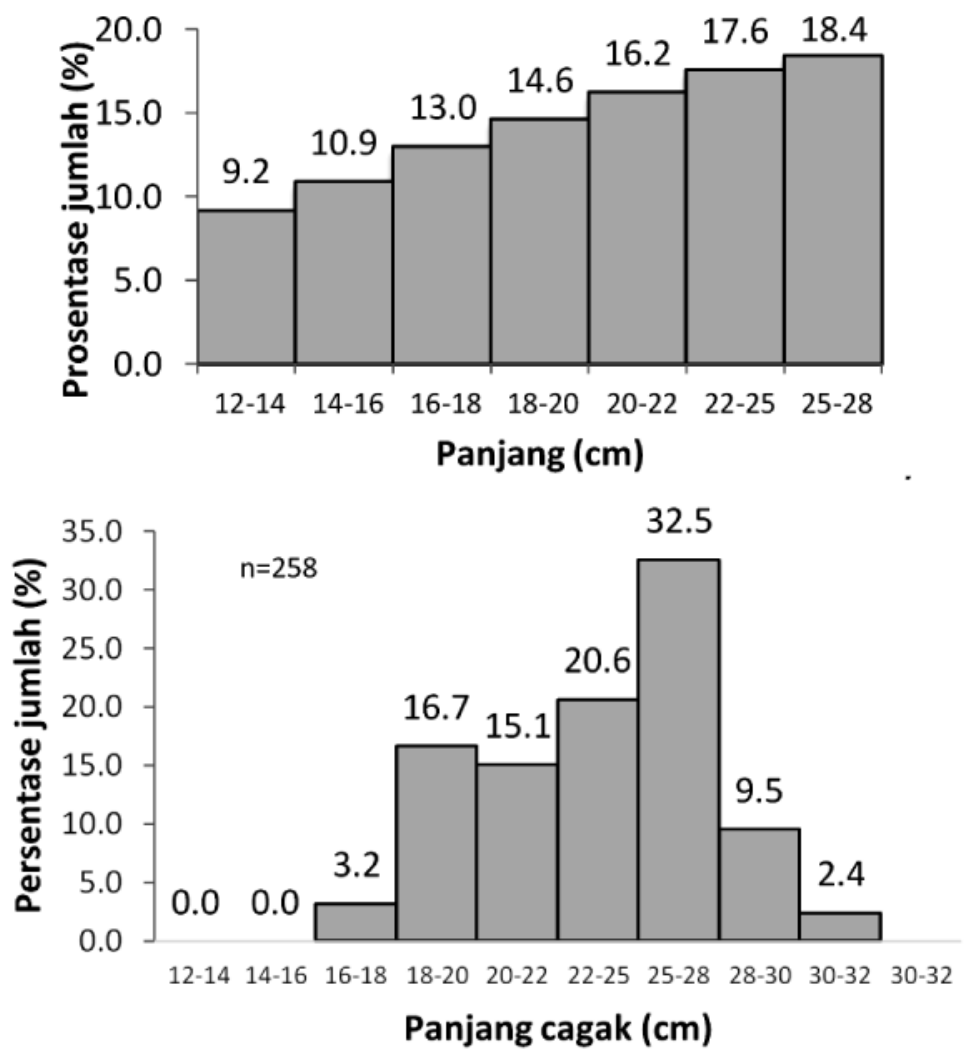

Gambar 4. Komposisi ukuran ikan pelagis kecil hasil observasi akustik (atas) dan hasil tangkapan (bawah). Figure 4. The composition of the size of small pelagic fish results of the acoustic observation (top) and catch (bottom).

Sementara untuk ikan pelagis besar didominasi oleh ukuran kelas modus panjang 31-34 cm dari hasil pengamatan hidroakustik, sedangkan hasil tangkapan didominasi ukuran ikan 34-37 cm (Gambar 5). 

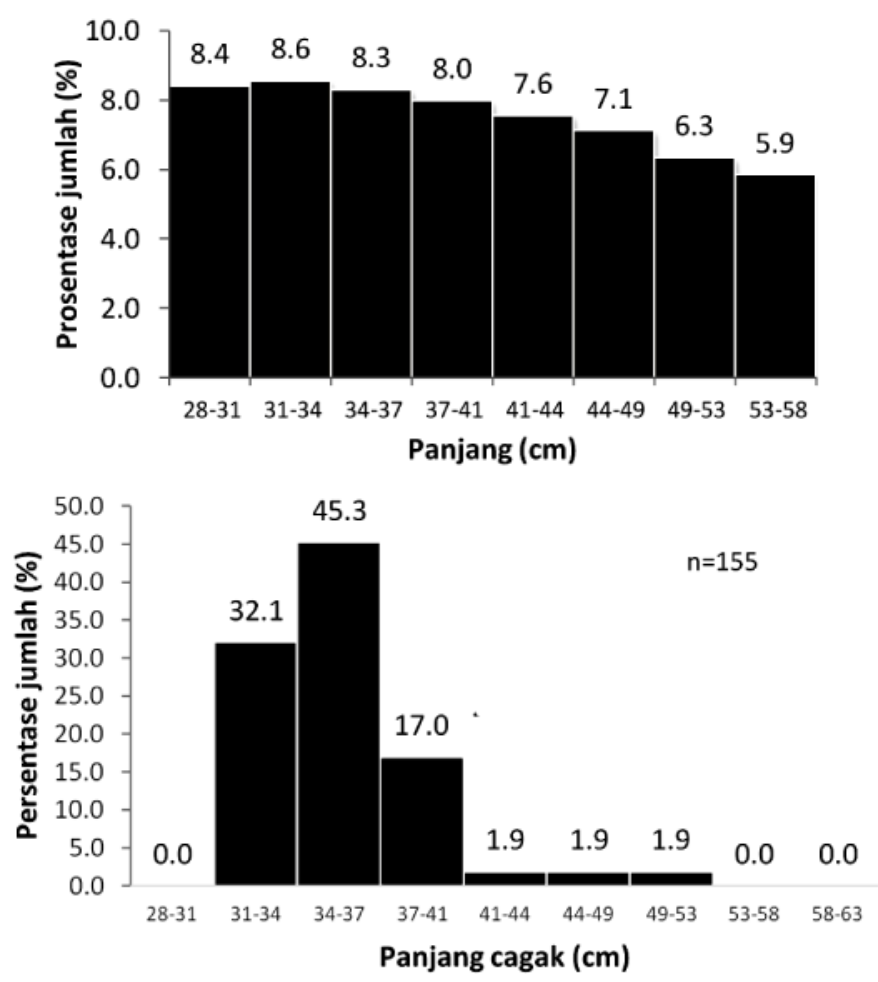

Gambar 5. Komposisi ukuran ikan pelagis besar hasil observasi akustik (atas) dan hasil tangkapan (bawah). Figure 5. The composition of the size of largepelagic fishresults of the acoustic observation (top) and catch (bottom).

Hasil pengamatan ikan pelagis pada saat survei eksplorasi, menunjukan jenis ikan pelagis kecil yang dominan tertangkap adalah ikan layang (Decapterus macarellus) sehingga model hubungan panjang dan bobot dari jenis ikan pelagis kecil yaitu $\mathrm{W}=0,049^{*} \mathrm{~L}^{3.292}$. Sedangkan model persamaan hubungan panjang dan bobot ikan pelagis besar adalah $\mathrm{W}=0,014^{*} \mathrm{~L}^{2.796}$ dan persamaan tersebut didapatkan dari ikan tongkol komo (Euthynnus affinis) yang merupakan ikan pelagis besar yang dominan tertangkap oleh nelayan di perairan WPP NRI 573.

\section{Distribusi Spasial Ikan Pelagis}

Distribusi jenis ikan pelagis secara spasial digambarkan dengan lingkaran berskala berwarna merah (pelagis kecil) dan kotak berskala berwarna biru (pelagis besar), apabila semakin besar menunjukan densitas tersebut memiliki nilai kepadatan yang tinggi (Gambar 6). Pada Gambar 6 tersebut juga terlihat distribusi ikan pelagis menyebar mulai dari selatan Jawa Barat sampai Selatan Nusa Tenggara. Distribusi ikan pelagis kecil tertinggi secara horizontal terdapat di selatan Cilacap sedang untuk pelagis besar di perairan selatan Jogyakarta.

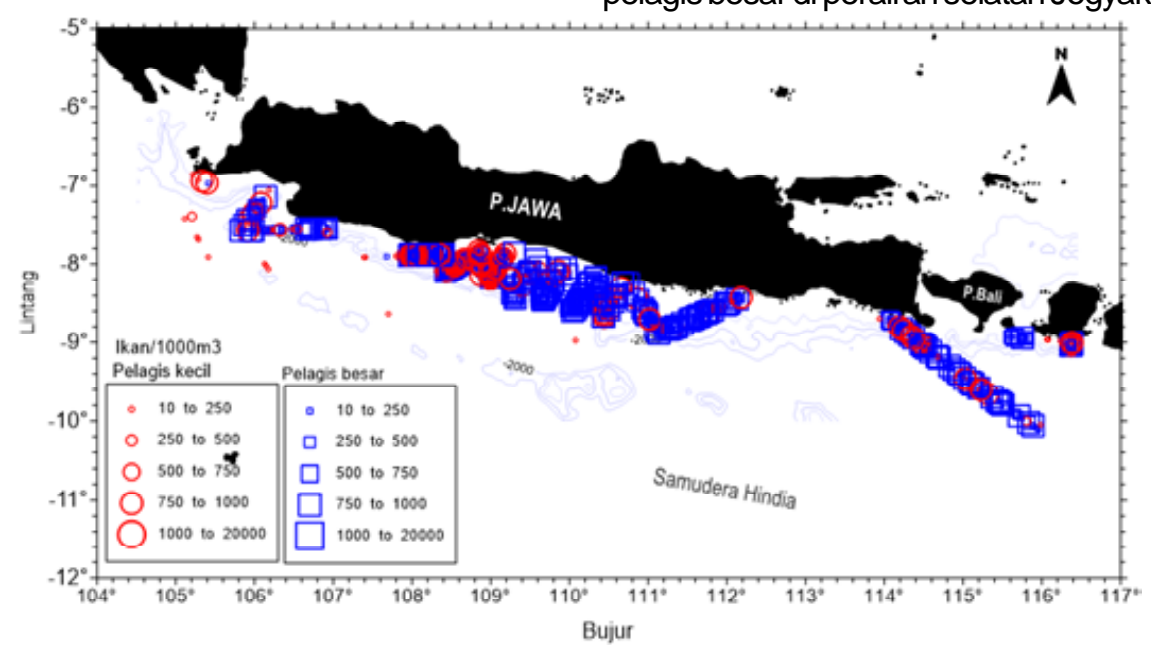

Gambar 6. Sebaran mendatar densitas ikan pelagis pada lapisan kedalaman 5-500 m di WPP NRI 573.

Figure 6. The horizontal distribution of the density of pelagic fish at depth layer of 5-500 m in FMA 573. 
Ikan pelagis kecil pada kedalaman 5-100 m ditemukan densitas tertinggi di perairan sekitar Pangandaran hingga wilayah Jogjakarta, dengan densitas rata-rata yaitu $1.703,63 \mathrm{~kg} / \mathrm{km}^{3}$. Untuk ikan pelagis besar ditemukan di daerah Jogjakarta mengarah ke arah timur hingga wilayah perairan Malang dengan nilai densitas terbesar $808,25 \mathrm{~kg} / \mathrm{km}^{3}$ (Gambar 6). Pada strata kedalaman 100-200 m nilai densitas terbesar yaitu $148,80 \mathrm{~kg} / \mathrm{km}^{3}$ untuk ikan pelagis kecil, sedangkan untuk ikan pelagis besar yaitu $468,75 \mathrm{~kg} / \mathrm{km}^{3}$ dan menyebar antara Cilacap hingga Jogjakarta. Distribusi ikan pada strata kedalaman 200-300 m menunjukkan bahwa nilai densitas ikan pelagis menurun seiring dengan bertambahnya kedalaman perairan. Pada strata kedalaman ini distribusi ikan pelagis kecil tertinggi sebesar $321,25 \mathrm{~kg} / \mathrm{km}^{3}$, ditemukan di sekitar Pangandaran, Cilacap, Jogjakarta dan Selat Bali. Untuk ikan pelagis besar ditemukan disekitar Pangandaran, Cilacap, Jogjakarta dan Selat Bali dengan indikasi densitas terbesar yaitu $369,03 \mathrm{~kg} /$ $\mathrm{km}^{3}$.

Distribusi ikan pelagis kecil pada strata kedalaman 300-400 m menunjukan distribusi tertinggi dengan densitas sebesar $391,99 \mathrm{~kg} / \mathrm{km}^{3}$, sedangkan distribusi pelagis besar yang paling tinggi dengan indikasi densitas sebesar $60,57 \mathrm{~kg} / \mathrm{km}^{3}$. Kelompok densitas pelagis kecil pada kedalaman $400-500 \mathrm{~m}$ terbesar ditemui yaitu $61,82 \mathrm{~kg} / \mathrm{km}^{3}$, sedangkan densitas pelagis besar terbesar ditemui yaitu $428,68 \mathrm{~kg} / \mathrm{km}^{3}$. Jenis ikan pelagis besar yang terdeteksi kemungkinan besar sama halnya pada lapisan bagian atas.

\section{Kepadatan Stok, Biomassa dan Potensi Lestari}

Dalam estimasi biomassa dan kepadatan stok ikan, ukuran ikan pelagis kecil yang dihitung didasarkan pada ukuran TS pada kisaran -60 sampai $-45 \mathrm{~dB}$ atau pada ukuran panjang $5-28 \mathrm{~cm}$ FL dengan kisaran bobot dari 1,7-127,6 gram. Sementara untuk ikan pelagis besar yang dihitung adalah ukuran TS -44 sampai $-37 \mathrm{~dB}$ atau pada ukuran panjang $28-58 \mathrm{~cm}$ FL dengan kisaran bobot dari 35,9-266,5 gram.

Kepadatan stok ikan pelagis menyebar pada berbagai strata kedalaman, dengan kepadatan yang cukup tinggi dibeberapa strata (Gambar 6).

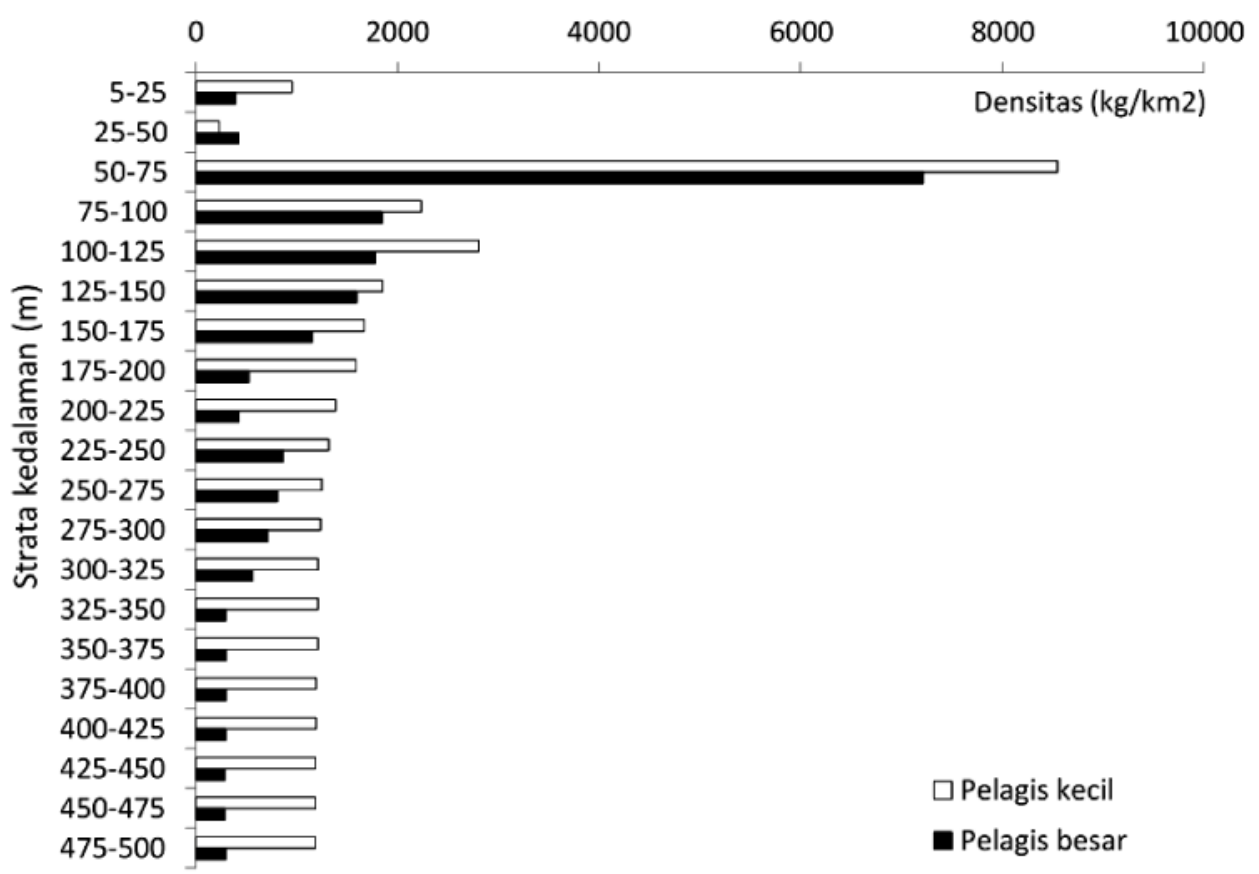

Gambar 6. Densitas total $\left(\mathrm{kg} / \mathrm{km}^{2}\right)$ ikan pelagis setiap strata kedalaman.

Figure 6. Total density $\left(\mathrm{kg} / \mathrm{km}^{2}\right)$ ) of pelagic fish by layer depth.

Estimasi biomassa dan kepadatan stok yang terdistribusi di perairan WPP NRI 573 dilakukan pada total luasan 2.055.302,03 km², dihitung dari batasan area WPP NRI 573.Nilai kepadatan stok terbesar tercatat sebesar $7.213 \mathrm{~kg} / \mathrm{km}^{2}$ untuk ikan pelagis besar dan $8.547 \mathrm{~kg} / \mathrm{km}^{2}$ untuk ikan pelagis kecil. 
Tabel 2. Komposisi ukuran, biomassa, dan kepadatan stok ikan pelagis kecil di WPP NRI 573 Table 2. The size composition, biomass, and density of small pelagic fish stocks in FMA 573

\begin{tabular}{|c|c|c|c|c|c|c|c|c|}
\hline Nilai TS (dB) & -60 & -59 & -58 & -57 & -56 & -55 & -54 & -53 \\
\hline Panjang (cm) & 5,0 & 5,6 & 6,3 & 7,1 & 7,9 & 8,9 & 10,0 & 11,2 \\
\hline Bobot (gram) & 1,7 & 2,3 & 3,1 & 4,1 & 5,4 & 7,2 & 9,6 & 12,8 \\
\hline Komposisi (\%) & 2,57 & 3,30 & 4,22 & 5,13 & 6,12 & 2,15 & 7,48 & 2,58 \\
\hline Densitas & 0,001 & 0,001 & 0,001 & 0,002 & 0,001 & 0,003 & 0,003 & 0,004 \\
\hline $\begin{array}{l}\text { Kepadatan } \\
\text { (ton/km2) }\end{array}$ & 0,001 & 0,003 & 0,004 & 0,007 & 0,011 & 0,005 & 0,024 & 0,011 \\
\hline Nilai TS (dB) & -52 & -51 & -50 & -49 & -48 & -47 & -46 & -45 \\
\hline Panjang (cm) & 12,5 & 14,1 & 15,8 & 17,7 & 19,9 & 22,3 & 25,0 & 28,1 \\
\hline Bobot (gram) & 17,1 & 22,8 & 30,4 & 40,5 & 54,0 & 72,0 & 95,9 & 127,9 \\
\hline Komposisi (\%) & 2,16 & 4,29 & 2,79 & 3,90 & 4,69 & 4,01 & 3,93 & 3,90 \\
\hline Densitas & 0,005 & 0,006 & 0,007 & 0,010 & 0,004 & 0,010 & 0,009 & 0,006 \\
\hline $\begin{array}{l}\text { Kepadatan } \\
\text { (ton/km2) }\end{array}$ & 0,012 & 0,032 & 0,028 & 0,052 & 0,084 & 0,096 & 0,125 & 0,165 \\
\hline
\end{tabular}

Sedangkan untuk rata-rata nilai kepadatan stok untuk ikan pelagis kecil dan ikan pelagis besar adalah sebesar 0,041 ton $/ \mathrm{km}^{2}$ dan sebesar 0,14 ton $/ \mathrm{km}^{2}$ (Tabel 2 dan 3).

Tabel 3. Komposisi ukuran, biomassa, dan kepadatan stok ikan pelagis besardi WPP NRI 573 Table 3. The size composition, biomass, and density of large pelagic fish stocks in FMA 573

\begin{tabular}{|c|c|c|c|c|c|c|c|c|}
\hline Nilai TS (dB) & -44 & -43 & -42 & -41 & -40 & -39 & -38 & -37 \\
\hline Panjang (cm) & 28,2 & 30,9 & 33,8 & 37,0 & 40,6 & 44.4 & 48.7 & 53,3 \\
\hline Bobot (gram) & 35,9 & 47,8 & 63,7 & 84,8 & 112,9 & 150,3 & 200,1 & 266,5 \\
\hline Komposisi (\%) & 3,99 & 8,12 & 7,19 & 4,94 & 4,48 & 3,56 & 3,15 & 1,33 \\
\hline Densitas & 0,016 & 0,006 & 0,009 & 0,010 & 0,004 & 0,006 & 0,003 & 0,004 \\
\hline Kepadatan (ton/km2) & 0,05 & 0,13 & 0,15 & 0,14 & 0,17 & 0,18 & 0,21 & 0,12 \\
\hline
\end{tabular}

Dari hasil perhitungan biomassa yang diperoleh kemudian diestimasi potensi lestari (MSY) ikan pelagis kecil sebesar 292.092 ton/tahun dan ikan pelagis besar sebesar 505.941 ton/tahun.

\section{Bahasan}

Melalui pola sebaran atau pengelompokkan sumberdaya ikan diharapkan dapat mengetahui pola agregasi, sehingga dapat memperoleh gambaran mengenai kondisi dari keberadaan sumberdaya ikan yang mendekati sebenarnya di alam. Ikan pelagis hampir terdeteksi pada semua strata kedalaman yaitu 5-500 m. Sutton (2010) menyatakan bahwa ikan pelagis dapat berenang hingga kedalaman deep scattering layer, dimana umumnya kedalaman tersebut terdapat pada 25-50\% kedalaman perairan. WPP NRI 573 memiliki perairan yang cukup dalam dengan ratarata kedalaman $>1000 \mathrm{~m}$. Penyebaran nilai densitas kemungkinan disebabkan faktor lingkungan atau keberadaan rumpon-rumpon yang menyebabkan ikan terkosentrasi pada lokasi-lokasi tertentu, seperti pada wilayah perairan Pacitan, Jogjakarta dan Cilacap (Widodo et al, 2012; Hargiatno et al., 2013).

Tingginya kepadatan stok ikan pelagis pada lokasi penelitian diduga karena banyaknya makanan dan suhu lingkungan yang sesuai dengan kondisi ikan. Tingginya unsur hara sebagai sumber makanan pada daerah berdasarkan parameter lingkungan yang diambil terindikasi bahwa terjadinya peristiwa upwelling pada lokasi penelitian. Adanya kenaikan massa air dari dasar perairan akibat pengaruh angin muson yang sering dikenal dengan istilah upwelling (Nontji, 1987; Nybakken, 1988; Purba, 1995) terjadipada lokasi, sehingga beberapa lokasi melimpah akan sumber makanan. Faktor makanan ini pula yang akan mempengaruhi pola pertumbuhan ikan tersebut (Monterio \& Oliviera, 2002). Jenis ikan pelagis besar yang dominan tertangkap saat survei oleh nelayan di WPP NRI 573 adalah tongkol komo (Euthynnus affinis) dengan persentase hasil tangkapan $29,28 \%$ dari total ikan pelagis yang tertangkap. Peningkatan jumlah rata-rata hasil 
tangkapan tongkol komo (Euthynnus affinis) antara tahun 2005-2014 sebesar 61,64\% (DJPT,2015). Dengan demikian ikan tongkol komo (Euthynnus affinis) digunakan perhitungan konversi panjang kedalam berat dalam estimasi biomassa ikan pelagis besar.

Pada kedalaman 200-300m nilai densitas cukup tinggi ditemukan pada beberapa lokasi yaitu pada perairan Cilacap dan selatan Jogjakarta. Keberadaan faktor makanan dan kondisi lingkungan berperan penting pada lapisan ini. Pada kedalaman ini proses tropic level cukup tinggi antara ikan pelagis (Baskoro, 2011). Ikan mesopelagis adalah ikan yang memiliki jumlah yang cukup banyak pada lapisan ini dan umumnya dalam keadaan dewasa (Utama \& Wudianto, 2016). Terdeteksinya kelompok pelagis kecil pada lapisan lebih dalam dibawah lapisan termoklin kemungkinan ikan tersebut termasuk kedalam jenis ikan mesopelagis. Keberadaaan ikan mesopelagis di Samudera Hindia dapat ditemukan hingga kedalaman perairan $600 \mathrm{~m}$ (Utama \& Wudianto, 2016). Ikan-ikan komersil penting seperti ikan tuna, billfish dan beberapa jenis ikan demersal bergantung pada ikan mesopelagis sebagai sumber makananya (Robertson \& Chivers, 1998).

Pada strata kedalaman lebih dalam ditemukan densitas yang cukup besar pada beberapa area penelitian.Keberadaan deep scattering layer yang memiliki bahan makanan yang cukup tinggi, mempengaruhi keberadaan ikan (Pena, 2014). Kelimpahan ikan pelagis besar cukup tinggi pada lapisan ini, ditemukan di sekitar selatan Pangandaran dan perairan selatan Perigi.

Kepadatan rata-rata ikan pelagis besar lebih banyak dibandingkan ikan pelagis kecil. Faktor penyebab rendahnya kepadatan stok ikan pelagis kecil karena adanya proses rantai makanan antar komoditas tersebut, hal ini dapat dilihat pada gambaran distribusi kedua komoditas tersebut yang saling berasosiasi. Hasil perhitungan potensi lestari (MSY) pada tahun 2016 menurut Komnas Kajiskan (Permen KP No.47 tahun 2016), jika dibandingkan dengan hasil kajian DJPT tahun 2014 (DJPT,2015) didapatkan potensi ikan pelagis kecil mengalami peningkatan sebesar $109 \%$ dan ikan pelagis besar sebesar $195 \%$.

\section{KESIMPULAN}

Stuktur ukuran ikan pelagis kecil didominasi oleh ukuran dewasa, sedangkan ikan pelagis besar didominasi oleh ukuran juvenil. Kepadatan ikan pelagis kecil menurun seiring bertambahnya kedalaman perairan, sebaliknya kepadatan ikan pelagis besar relatif lebih meningkat. Kepadatan ikan banyak ditemui pada beberapa lokasi seperti di perairan selatan Pangandaran, Cilacap, Jogjakarta dan sekitar Selat Bali. Rata-rata kepadatan stok ikan pelagis kecil sebesar 0,041 ton $/ \mathrm{km}^{2}$ dan 0,14 ton $/ \mathrm{km}^{2}$ untuk ikan pelagis besar dan diperoleh potensi lestari ikan pelagis kecil sebesar 292.092 ton/tahun dan ikan pelagis besar sebesar 505.941 ton/tahun. Untuk pengelolaan perikanan tangkap yang lestari perlu dilakukan pembatasan penangkapan sesuai potensi lestarinya.

\section{PERSANTUNAN}

Tulisan ini merupakan kontribusi dari hasil kegiatan tim peneliti BPPL dan teknisi kapal KR.Baruna Jaya IV pada kegiatan penelitian Karakteristik Biologi Perikanan, Habitat Sumber Daya dan Produksi Sumber Daya Ikan di WPP NRI 573 T.A.2015, Balai Penelitian Perikanan Laut-Muara Baru, Jakarta.

\section{DAFTAR PUSTAKA}

Anonimus. (2016). Keputusan Menteri Kelautan dan Perikanan Nomor: 47/Kepmen-KP/2016 tentang Estimasi potensi, jumlah tangkapan yang diperbolehkan dan tingkat pemanfaatan sumber daya ikan di wilayah pengelolaan perikanan Negara Republik Indonesia.

Anonimus. (2009). Peraturan Menteri Kelautan dan Perikanan Republik Indonesia Nomor Per.01/Men/ 2009 tentang Wilayah Pengelolaan Perikanan Republik Indonesia.

Baskoro, M. S., Taurusman, A.A., \& Sudirman. (2011). Tingkah Laku Ikan Hubunganya dengan IImu dan Teknologi Perikanan Tangkap (p 258). Bandung: Lubuk Agung.

Bertrand, A., \& Edward, J. (2000). Tuna target strength related to fish length and swimbladder volume. ICES Journal of Marine Science, 57,143-1146.

DJPT. (2015). Statistik perikanan tangkap di laut menurut Wilayah Pengelolaan Perikanan Negara Republik Indonesia (WPP-NRI) 2005-2014. Jakarta: Kementerian Perikanan dan Kelautan.

Effendi, M. I. (2002). Biologi Perikanan (p. 116). Jakarta: Yayasan Pustaka Nusantara.

Hannachi, M.S., Abdallah, L. B., \& Marrakchi, O. (2004). Acoustic identification of small-pelagic fish species: target strength analysis and school de- 
scriptor classification. MedSudMed Technical Documents No.5.

Hargiatno, I.T., Regi, F.A., \& Wudianto. (2013). Perikanan Pancing Ulur di Pelabuhanratu: Kinerja Teknis Alat Tangkap. J.Lit.Perikan.Ind. 19(3), 121130.

Kim, Z.G., Choi, Y.M., Hwang, K.S., \& Yoon, G.D. (1998). Study on the acoustic behavior pattern of fish school and species identification. Shoal behavior pattern of anchovy (Engraulis japonicus) in Ko-rean waters and species identification test. J.Kor.Soc.Fish.Techno. 34, 52-61.

Korneliussen, R.J., Heggelund, Y., Eliassen, I.K., \& Johansen, G.O. (2009).Acoustic species identification of schooling fish. ICES, J.Mar.Sci. 66, 11111118.

Lee, D.J. (2012). Fish length dependence of target strength for black porgy and fat greenling at two frequencies of 70 and $120 \mathrm{kHz}$. J.Kor.Soc.Fish. Technol. 48, 137-146.

Lee, D.J., \& Shin, H.I. (2005). Construction of a data bank for acoustic target strength with fish species, length and acoustic frequency for measuring fish size distribution. J.Kor.Fish.Soc. 38, 265275.

Lee, D.J., Shin, H.I., \& Shin, H.H. (1995). Fish stock assessment by hy-droacoustic methods and it's applications - I - Estimation of fish school target strength. J.Kor.Soc.Fish.Techno. 31, 142-15.

Monterio, R., \& Oliveira. (2002). Fish Growth Modelling Growth of the European anchovy (Engraulis encrasicolus) in the Tagus Estuary, Portugal. (Theses) Unpublished Diplome D'Etudes Approfondies Europeen en Modelisation de L'Environment Marin, DEA. Portugal: Technical University of Lisbon.

Mun, J.H., Lee, D. J., Shin, H.I., \& Lee, Y.W. (2006). Fish length dependence of target strength for black rockfish, goldeye rockfish at $70 \mathrm{kHz}$ and $120 \mathrm{kHz}$. J.Kor.Soc.Fish. Techno. 42, 30-37.

Nontji, A. (1987). Laut Nusantara (p.368). Jakarta: Djambatan
Nybakken, J.W. (1988). Biologi Laut, suatu pendekatan ekologi (p.459). Jakarta: PT.Gramedia.

Pena, M.,Rosa, B., Jose, L. L. J., Magdalena, I., \& Joan, M. (2014).Acoustic detection of mesopelagic fishes in scattering layers of the Balearic Sea (Western Mediterranean). J.Fish.Aquatic.Science. NRC: Research Press.

Purba, M. (1995). Evidence of Upwelling and its Generation Stage off Southern West Jawa During Souteast Monsoon. Bul.ITK. Maritek. 5 (1), 21 39.

Simmonds, E.J., \& MacLennan, D. N. (2005). Fisheries Acoustic: Theory and Practice 2nd ed. UK: Blackwell Science Ltd.

Suman, A, Wudianto, Bambang S, Hari E.I, Badrodin, Khairul, A. (2014). Potensi dan Tingkat Pemanfaatan Sumberdaya Ikan di Wilayah Pengelolaan Perikanan Republik Indonesia (WPP RI). Jakarta: Ref Graphika.

Sutton, T. T., Wiebe, P.H., Madin, L.P., \& Bucklin, A. (2010). Diversity and community structure of pelagic fish to $5000 \mathrm{~m}$ depth in the Sargasso Sea. Deep-Sea Researchll. Topical Studies in Oceanography. 57, 2220-2233.

Sparre, P., \& Venema, S.C. (1998). Introduction to tropical fish stock assessment. Part 1.Manual. Roma: FAO Fisheries Technical Paper.

Utama, A.A., \& Wudianto. (2016). Dinamika spatial ikanmesopelagis (Ceratoscopelus warmingiiLÜTKEN, 1892) di Samudera Hindia. J.Lit.Perik.Ind. 22(4), 263-270.

Widodo, A.A., Budi, I.P., \& Suprapto. (2012). Perikanan Pancing Ulur di Samudera Hindia: Hasil Tangkapan Ikan Berparuh yang di Daratkan di Sendangbiru, Malang, Jawa timur. J.Lit.Perikan.Ind. 18(3), 167-173.

Yoon, G.D., \& Ha, K.L. (1998). Acoustic target strength of pelagic fish species to echo integration in Korea Waters and Measurement of target strength of squid ( Todarodes pacificus). J Kor Soc Fish Techno. 34, 372-377. 